\title{
Latihan Yoga Dapat Menurunkan Tingkat Kecemasan pada Siklus Mentruasi Remaja Puteri
}

\author{
Yulinda $^{1}$, Dewi Purwaningsih ${ }^{1}$, Cherly Marlina Sudarta ${ }^{1}$ \\ 1 Jurusan kebidanan Bandung Poltekkes Kemenkes Bandung \\ Jl. Sederhana No.2, Pasteur, Sukajadi, Kota Bandung, Jawa Barat 40161 \\ Email: yulinda_aja@yahoo.com
}

\begin{abstract}
Abstrak
Setiap bulan perempuan berusia 12-49 tahun (WUS), tidak sedang hamil dan belum menopause mengalami menstruasi. Pada saat menstruasi masalah yang dialami banyak wanita adalah rasa tidak nyaman atau rasa nyeri. Dismenorea mengakibatkan absentisme dan menimbulkan kerugian, karena mengalami "kelumpuhan" sementara dalam melakukan aktivitas. Perubahan fungsi sistem syaraf otonom selama fase luteal menstruasi berhubungan dengan gejala psikosomatik pada fase menstruasi. Alternatif preventif untuk meningkatkan kesehatan perempuan adalah dengan melakukan yoga. Yoga memberikan manfaat pada kesehatan fisik dan mental melalui pengaturan sumbu HPA (Hipothalamus Pitutari Adrenal) dan System Syaraf Simpatis, meningkatkan aktifitas parasimpatis, menurunkan tekanan darah menurunkan stress dan tingkat kecemasan. Gerakan-gerakan fisik dari yoga merangsang, menguatkan tubuh serta meningkatkan sirkulasi darah. Organorgan panggul, otot-otot perineal dan panggul menjadi lebih sehat, mendapatkan asupan oksigen, sehingga vaskularisasi menuju organ reproduksi menjadi optimal. Penelitian ini bertujuan untuk mengetahui pengaruh latihan Yoga terhadap tanda tanda vital dan tingkat kecemasan pada siklus menstruasi remaja putri. Penelitian dilakukan dengan desain quasi eksperimen one group pretest-postest. Penelitian ini dilaksanakan di Jurusan Kebidanan Bandung, yaitu mahasiswa remaja puteri. Intervensi berupa Yoga pada bulan Mei-Juli 2015. Pengambilan sampel menggunakan teknik stratified random sampling berdasarkan tingkat serta memenuhi kriteria inklusi sejumlah 121 orang, diseleksi dengan kriteria inklusi, yaitu sejumlah 58 orang dirandom untuk yoga dan olahraga. Pengukuran tanda tanda vital dengan pengukuran langsung dan tingkat kecemasan dengan menggunakan kuesioner. Penurunan tekanan diastolik lebih banyak terjadi pada kelompok olahraga, yaitu sebesar 4,50 sedangkan yoga sebesar 0,55. Pada kelompok yoga terjadi penurunan frekuensi denyut nadi yakni sebesar 1,83. Skor kecemasan terjadi penurunan kelompok yoga lebih banyak mengalami penurunan skor cemas yaitu sebesar 13,5 poin. Kesimpulan tidak terdapat pengaruh yang signifikan latihan yoga terhadap tekanan sistolik, diastolik, frekuensi nadi dan pernafasan. Yoga secara signifikan dapat menurunkan tingkat kecemasan remaja puteri pada saat menstruasi $(p<0,05)$.
\end{abstract}

Kata Kunci: yoga, tanda vital, tingkat kecemasan, mestruasi remaja

\section{Yoga Exercise Can Reduce Anxiety Level of Girl Adolescent Menstrual Cycle}

\begin{abstract}
Every month women aged 12-49 years, not pregnant and not yet experienced menopause has menstruation. During this period, problems experienced by many women are discomfort or pain. Dysmenorrhoea resulted absenteism and cause disadvantages, due to a temporary "paralysis" while doing activities. The autonomic nervous system function changes during the luteal phase of the menstrual period, is associated with psychosomatic symptoms in the menstrual phase. A preventive alternative to improve women's health is by doing yoga. Yoga provides benefits to physical and mental health through the regulation of the HPA axis (Hypothalamus Pituitary Adrenal) and the Sympathetic Nervous System, increasing parasympathetic activity, lowering blood pressure, stress and anxiety levels. The physical movements of yoga stimulates, strengthens the body and improve blood circulations. Pelvic organs, perineal muscles and pelvic become healthier, get oxygen, so that the vascularization toward the reproductive organs become optimal. The purpose of this
\end{abstract}


research is to know effect of Yoga to vital sign and anxiety level in girl adolescent menstrual cycle. The study was a quasi-experimental design with one group pretest-posttest. This research was carried at the Bandung Midwifery Department, to the student girls. Intervention in the form of Yoga was held in May-July 2015. A number of 121 people were taken as a sample using a stratified random sampling technique based on student level and inclusion criteria and 58 people selected by inclusion criteria, which were randomly assigned to yoga and exercise. Vital signs were measured directly and anxiety level using questionnaires. The results showed that reduction in diastolic pressure occurs more frequently in the exercise group, amounting 4.50 while yoga at 0.55 . In the yoga group decreased pulse frequency which is equal to 1.83. Anxiety scores decreased more in the yoga group, the reduction in anxiety scores in the amount of 13.5 points. In conclusions there was no significant effect of yoga exercises to systolic pressure, diastolic, pulse and respiration. Yoga can significantly reduce the level of girls anxiety during menstruation ( $p$ 0.05).

Keywords: yoga, vital signs, anxiety level, menstrual teenagers

Info Artikel:

Artikel dikirim pada 03 Agustus 2016

Artikel diterima pada 10 Maret 2017

DOI : http://dx.doi.org/10.21927/jnki.2017.5(1).20-26

\section{PENDAHULUAN}

Setiap bulan perempuan berusia 12-49 tahun wanita usia subur (WUS), tidak sedang hamil dan belum menopause pada umumnya mengalami menstruasi. Pada saat menstruasi masalah yang dialami banyak perempuan adalah rasa tidak nyaman atau rasa nyeri yang hebat yang disebut dismenorea (dysmenorrhoea). Menurut Novia, tidak ada angka pasti mengenai jumlah penderita nyeri haid di Indonesia. Di Amerika Serikat, nyeri haid didapatkan $30-70 \%$ wanita dalam usia reproduksi, serta $60-70 \%$ pada perempuan dewasa yang tidak menikah. Penelitian di Swedia dijumpai 30\% wanita pekerja industri menurun penghasilannya karena nyeri haid. Kelainan terjadi pada $60-70 \%$ wanita di Indonesia dengan $15 \%$ diantaranya mengeluh bahwa aktivitas mereka menjadi terbatas akibat dismenorea (1).

Menurut Novia, di Kelurahan Banjar Kemantren yang mengalami dismenorea primer adalah sebesar $80 \%$. Dari $80 \%$ yang mengalami nyeri haid, derajat kesakitannya berbeda yaitu $40 \%$ mengatakan nyeri ringan, $30 \%$ nyeri sedang dan $10 \%$ nyeri hebat. Sebagian besar dialami oleh remaja yang kurang melakukan olahraga. Hal ini berarti bahwa penderita dismenorea primer sangat banyak sehingga dampaknya dapat mempengaruhi absentisme dan menimbulkan kerugian materi, karena mengalami "kelumpuhan" sementara untuk melakukan aktivitas. Dismenorea ini memang tidak terlalu berbahaya tetapi selalu dialami oleh perempuan setiap bulannya, sehingga merupakan penderitaan tersendiri bagi yang mengalaminya (1).
Stres premenstrual ditandai dengan adanya perubahan fisik, psikologi dan perilaku, yang kejadiannya mencapai $75 \%$ perempuan usia produktif. Akibat fluktuasi hormon fisiologis pada perempuan yang terjadi secara regular dan siklik. Beberapa penelitian menyebutkan bahwa perubahan fungsi system syaraf otonom selama fase luteal berhubungan dengan kejadian gejala psikosomatik yang muncul pada fase menstruasi, hal ini dapat berdampak terhadap produktifitas perempuan pada saat menstruasi (2). Berdasarkan data Survei Ketenagakerjaan Nasional (Sukernas) tahun 2011, Tingkat Partisipasi Angkatan Kerja (TPAK) perempuan sekitar 52,44\%, jika dibandingkan dengan TPAK laki-laki sebesar $84,30 \%$ dapat dikatakan rendah, namun dengan bertambah lamanya pendidikan, kebutuhan sosial dan ekonomi keluarga mendorong perempuan untuk dapat berpartisipasi sebagai tenaga kerja. Tenaga kerja produktif dituntut untuk mendapatkan output pekerjaannya. Begitupun remaja perempuan diharapkan dapat tetap produktif meskipun premenstrual sindrom dirasakan ketika sedang mengalami menstruasi.

Berdasarkan pengamatan yang dilakukan ditemukan beberapa remaja puteri di Jurusan kebidanan Bandung seringkali tidak mengikuti proses pembelajaran dan tidak dapat hadir saat kuliah karena sakit saat menstruasi yang berakibat pada berkurangnya persentase kehadiran mahasiswa yang berdampak terhadap berkurangnya penguasaan mahasiswa terhadap topik yang tidak dihadiri dan tidak memenuhinya persyaratan mengikuti ujian. Penelitian 
Zaafrane, menyebutkan sakit saat menstruasi dapat diatasi melalui pemberian obat obatan, namun berefek samping sehingga therapy yang bersifat nonfarmakologis sangat dianjurkan (3). Alternatif lain yang bersifat preventif dan dapat meningkatkan kesehatan perempuan adalah dengan melakukan latihan yoga. Penelitian menunjukkan bahwa latihan yoga memberikan manfaat pada kesehatan fisik dan mental melalui pengaturan sumbu HPA (Hipothalamus Pitutari Adrenal) dan System Syaraf Simpatis (4). Terjadi penurunan tingkat kecemasan postmenstrual dan premenstrual pada kelompok setelah latihan yoga adalah 32,4 menjadi 23,5; $p=00,1$ (4).

Saat ini latihan fisik telah dilakukan di bangku sekolah dengan latihan yang bersifat umum yang diikuti oleh laki-laki dan perempuan. Latihan yoga sebagai alternatif latihan dapat mengurangi premenstrual syndrome. Belum terdapatnya data mengenai absentisme akibat dismenorea, jumlah ketidakhadiran remaja puteri karena ketidaknyamanan saat menstruasi serta ketidaktahuan remaja puteri untuk mengatasinya menjadi salah satu hal yang menjadi minat untuk melakukan penelitian ini. Tujuan Penelitian ini adalah untuk mengetahui pengaruh latihan Yoga terhadap tanda tanda vital dan tingkat kecemasan pada siklus menstruasi remaja putri.

\section{BAHAN DAN METODE}

Penelitian ini dilakukan dengan desain quasi eksperimen menggunakan rancangan penelitian one group pretest-postest. Lokasi Penelitian remaja puteri pada Jurusan Kebidanan Bandung. Pelaksanaan intervensi berupa latihan Yoga dilaksanakan pada bulan Mei-Juli 2015. Analisis data dalam penelitian ini adalah analisis univaribel dan bivariabel. Analisis bivariabel sebelum dan sesudah diberi perlakuan maka digunakan uji beda dua mean berpasangan (paired sample t-test). Untuk melihat adanya perbedaan nilai rata-rata skor tanda-tanda vital (sistolik, diastolik, respirasi dan nadi) dan rata-rata skor cemas, pada kelompok perlakuan dengan kelompok kontrol digunakan uji beda dua mean tidak berpasangan (independent sample t-test). Pengukuran tingkat kecemasan dapat menggunakan Psychological parameters: BAI (Beck Anxiety Inventory) (5). Dikelompokkan menjadi 3 tingkatan yaitu ringan (skor 0-21), sedang (22-35), dan berat (>36).

\section{HASIL DAN BAHASAN}

\section{Pengaruh Yoga terhadap Tekanan Sistolik, Diastolik, Nadi dan Pernafasan}

Responden pada penelitian ini terdiri dari 30 orang. Distribusi mean pada masing-masing perlakuan tampak pada Tabel 1 dan Tabel 2.

Perbedaan mean bulan 1 dan bulan 2 yang tampak pada Tabel 1 menginformasikan bahwa untuk tekanan sistolik pada kedua kelompok mengalami penurunan, penurunan lebih besar terjadi pada kelompok yoga sebesar 3,33 sedangkan pada kelompok olah raga sebesar 0,75 . Pada tekanan

Tabel 1. Distribusi Rata Rata Mean Tanda Tanda Vital dan Tingkat Kecemasan Remaja Puteri pada Kelompok Yoga dan Olah Raga Bulan 1 dan 2

\begin{tabular}{ccccccccc}
\hline \multirow{2}{*}{ Variabel } & \multicolumn{3}{c}{ Yoga } & \multicolumn{3}{c}{ Olah Raga } \\
\cline { 2 - 10 } & Mean & $\begin{array}{c}\text { Standar } \\
\text { Deviasi }\end{array}$ & Min & Max & Mean & $\begin{array}{c}\text { Standar } \\
\text { Deviasi }\end{array}$ & Min & Max \\
\hline Sistolik 1 & 108,89 & 10,22 & 90 & 130 & 106,58 & 7,63 & 90 & 119 \\
Sistolik 2 & 105,56 & 10,96 & 90 & 120 & 105,83 & 11,64 & 90 & 120 \\
Delta sistolik & 3,33 & 13,28 & $-20,00$ & 30,00 & 0,75 & 7,90 & $-10,00$ & 10,00 \\
Diastolik 1 & 70,56 & 8,02 & 60 & 90 & 72,58 & 9,55 & 60 & 87 \\
Diastolik 2 & 70,00 & 9,07 & 60 & 80 & 68,08 & 6,70 & 60 & 80 \\
Delta Diastolik & 0,55 & 9,98 & $-20,00$ & 10,00 & 4,50 & 7,39 & $-5,00$ & 18,00 \\
Nadi 1 & 74,00 & 7,65 & 68 & 100 & 78,50 & 5,91 & 66 & 86 \\
Nadi 2 & 72,17 & 4,70 & 68 & 89 & 80,08 & 7,39 & 65 & 88 \\
Delta Nadi & 1,83 & 5,02 & $-5,00$ & 11,00 & $-1,58$ & 6,78 & $-18,00$ & 10,00 \\
Respirasi 1 & 19,94 & 1,43 & 18 & 23 & 17,75 & 1,60 & 16 & 20 \\
Respirasi 2 & 20,56 & 1,43 & 18 & 24 & 19,08 & 0,99 & 17 & 20 \\
Delta Respirasi & $-6,11$ & 1,37 & $-2,00$ & 2,00 & $-1,33$ & 2,22 & $-4,00$ & 3,00 \\
Skor Cemas 1 & 28,11 & 11,67 & 8 & 49 & 11,92 & 10,19 & 2 & 36 \\
Skor Cemas 2 & 14,61 & 8,81 & 4 & 42 & 8,50 & 8,79 & 0,26 & 26 \\
Delta Cemas & 13,50 & 10,33 & $-8,00$ & 30,00 & 3,41 & 9,81 & $-11,00$ & 29,00 \\
\hline
\end{tabular}


Tabel 2. Distribusi Mean pada Kelompok Yoga dan Olah Raga Bulan 1 dan 3

\begin{tabular}{ccccccccc}
\hline \multirow{2}{*}{ Variabel } & \multicolumn{4}{c}{ Yoga } & \multicolumn{4}{c}{ Olah Raga } \\
\cline { 2 - 9 } & Mean & $\begin{array}{c}\text { Standar } \\
\text { Deviasi }\end{array}$ & Min & Max & Mean & $\begin{array}{c}\text { Standar } \\
\text { Deviasi }\end{array}$ & Min & Max \\
\hline Sistolik 1 & 108,9 & 10,22 & 90 & 130 & 106,58 & 7,63 & 90 & 119 \\
Sistolik 2 & 105,56 & 10,96 & 90 & 120 & 105,83 & 11,64 & 90 & 120 \\
Delta sistolik & 3,33 & 13,28 & 20 & 30 & 0,75 & 7,94 & -10 & 10,00 \\
Diastolik 1 & 70,56 & 8,02 & 60 & 90 & 72,58 & 9,55 & 60 & 87 \\
Diastolik 2 & 70,00 & 9,07 & 60 & 80 & 68,08 & 6,70 & 60 & 80 \\
Delta Diastolik & 0,55 & 9,98 & -20 & 10 & 4,50 & 7,39 & $-5,00$ & 18,00 \\
Nadi 1 & 74,00 & 7,65 & 68 & 100 & 78,50 & 5,91 & 66 & 86 \\
Nadi 2 & 72,17 & 4,70 & 68 & 89 & 80,08 & 7,39 & 65 & 88 \\
Delta Nadi & 1,83 & 5,02 & $-5,00$ & 11,00 & $-1,58$ & 6,78 & $-18,00$ & 10,00 \\
Respirasi 1 & 19,94 & 1,43 & 18 & 23 & 17,75 & 1,60 & 16 & 20 \\
Respirasi 2 & 20,56 & 1,42 & 18 & 24 & 19,08 & 0,99 & 17,00 & 20,00 \\
Delta Respirasi & $-0,61$ & 1,37 & $-2,00$ & 2,00 & $-1,33$ & 2,22 & $-4,00$ & 3,00 \\
Skor Cemas 1 & 28,11 & 11,67 & 8 & 49 & 11,92 & 10,19 & 2 & 36 \\
Skor Cemas 2 & 16,00 & 6,57 & 6 & 33 & 9,42 & 9,75 & 1 & 35 \\
Delta Cemas & 13,5 & 10,33 & $-8,00$ & 30,00 & 3,41 & 9,81 & $-11,00$ & 29,00 \\
\hline
\end{tabular}

diastolik lebih banyak terjadi penurunan pada kelompok olah raga dibandingkan kelompok yoga $(4,50$ dan 0,55$)$. Peningkatan terjadi pada mean respirasi kedua kelompok, peningkatan lebih besar terjadi pada kelompok yoga sebesar 6,11 . Skor kecemasan terjadi penurunan pada kedua kelompok dan lebih banyak penurunan terjadi pada kelompok yoga senilai 13,5 .

Berdasarkan Tabel 2 menjelaskan bahwa ratarata mean pada kelompok yoga dan olahraga terdapat penurunan sistolik, penurunan terjadi juga pada tekanan diastolik sebesar 1,83 pada kelompok yoga. Penurunan tingkat kecemasan terdapat penurunan pada kedua kelompok intervensi, terutama pada kelompok yoga sebesar 13,5 poin.

Yoga adalah suatu proses penyatuan dari tubuh (body), pikiran (mind) dan jiwa (soul). Yoga mengkombinasikan teknik bernapas, relaksasi dan meditasi serta latihan peregangan. Yoga dianjurkan karena memiliki efek relaksasi yang dapat meningkatkan sirkulasi darah ke seluruh tubuh. Sirkulasi darah yang lancar, mengindikasikan kerja jantung yang baik. Penelitian menemukan bahwa kombinasi antara yoga, meditasi dapat meningkatkan metabolisme tubuh.

Semakin bertambahnya usia, maka terjadi perubahan struktur dan fungsi pada aorta. Hal ini yang mengakibatkan kekakuan, penurunan elastisitas dan penebalan pada dinding aorta. Penebalan pada dinding aorta disebabkan oleh peningkatan serat kolagen dan hilangnya serat elastis dalam lapisan medial arteri. Penebalan ini mengakibatkan penyempitan pada aliran darah aorta selama denyut sistol (1).

Hormon estrogen berperan merangsang maturasi pada organ reproduksi dan pemeliharaan struktur normal kulit dan pembuluh darah. Jika produksi hormon estrogen terus menurun dengan bertambahnya usia, maka fungsi untuk pemeliharaan struktur normal pembuluh darah juga akan menurun. Penurunan tekanan darah, disebabkan karena responden dalam penelitian dapat mengikuti instruksi peneliti dengan baik. Sehingga, manfaat pada latihan yoga selama 12 kali berturut-turut dapat menunjukan hasil yang optimal.

Stress dapat meningkatkan sistem simpathetik sehingga meningkatkan kontraksi uterus dengan berolahraga aktifitas sistem simpathetic menurun sehingga mengurangi keluhan nyeri. Menurut Matsumoto, tidak ada perbedaan frekuensi denyut jantung dalam siklus haid. Frekuensi nadi menurun pada fase luteal dibandingkan pada fase folicullar. Penelitian matsumoto menunjukkan bahwa aktifitas sistem syaraf parasimpatis menurun pada fase luteal dibandingkan pada fase folikular (2).

Latihan yoga secara teratur dapat menyeimbangkan sistem saraf otonom, sehingga tubuh menjadi lebih relaks dan pengeluaran hormonhormon yang berperan dalam peningkatan tekanan darah, seperti hormon adrenalin dan eprineprin lebih terkontrol. Latihan yoga membuat system saraf otonom menjadi seimbang dan tenang yang bermanfaat untuk menurunkan tekanan darah. Ada berbagai macam jenis latihan yoga, yang 
intinya menggabungkan antara teknik bernapas (pranayama), relaksasi dan meditasi, serta latihan peregangan. Bernapas dengan cepat dan dangkal akan mengurangi jumlah oksigen yang tersedia dan otak akan bereaksi terhadap hal ini dengan panik. Bagian dari proses panik adalah peningkatan denyut jantung dan peningkatan tekanan darah.

Dengan mengatur napas menjadi lebih pelan dan dalam akan membuat peregangan pada otototot tubuh, sehingga menyebabkan tubuh dan pikiran menjadi lebih relaks, nyaman dan tenang yang membuat penurunan pada tekanan darah. Pranayama (teknik bernapas) pada yoga berfungsi untuk menenangkan pikiran dan tubuh yang membuat detak jantung lebih tenang sehingga tekanan darah dan produksi hormon adrenalin menurun.

Yoga bertujuan untuk merangsang gelombang alfa pada otak yang terhubung dengan kondisi relaksasi yang mendalam dan kesehatan mental, hal ini dapat menurunkan tekanan darah. Latihan peregangan secara teratur dapat menguatkan otot jantung yang mengakibatkan jantung dapat memompa lebih banyak darah dengan usaha yang minimal. Sehingga, kerja jantung menjadi lebih ringan. Latihan peregangan juga dapat meningkatkan metabolisme lemak dengan menurunkan kadar lipoprotein densitas rendah (LDL) dan meningkatkan kadar lipoprotein densitas tinggi dengan meningkatkan denyut jantung dan respon sistem saraf simpatik, sehingga pembuluh darah berkontraksi dan tekanan darah dipertahankan.

Latihan yoga secara teratur dijelaskan sebagai salah satu cara mencegah dan mengobati dysmenorrhoea, akibat dari tingkat hormon steroid dalam sirkulasi darah pada remaja sehingga meningkatkan hormon endorphin yang dapat meningkatkan ambang nyeri saat menstruasi (6). Yoga memiliki efek fisiologis pada kekuatan otot, peningkatan beberapa asanas (posisi tubuh) yang dipercaya dapat mempengaruhi sistem saraf otonom dan kelenjar endokrin yang mengatur fungsi internal termasuk detak jantung dan produksi hormon (7).

\section{Pengaruh Yoga terhadap Kecemasan}

Perbedaan rerata tanda-tanda vital dan skor kecemasan disajikan dalam Tabel 3 dan Tabel 4. Berdasarkan Tabel 4 setelah dilakukan uji normalitas data dengan Kolmogorov-Smirnov, nilai rerata variabel memiliki distribusi data yang tidak normal sebelum dan setelah perlakuan. Hasil uji statistik menunjukan terdapat pengaruh yang bermakna antara sebelum
Tabel 3. Perbedaan Rerata Tandatanda Vital dan Skor Kecemasan Bulan Pertama dan Bulan ke 2

\begin{tabular}{|c|c|c|c|c|}
\hline Intervensi/variabel & Rerata & SD & $p$-value & $\mathrm{Cl} 95 \%$ \\
\hline \multicolumn{5}{|c|}{ Latihan Yoga } \\
\hline Tekanan Sistolik & 2,86 & 3,66 & 0,44 & $-4,65-10,37$ \\
\hline Tekanan Diastolik & $-1,02$ & 3,45 & 0,76 & $-8,11-6,05$ \\
\hline Nadi & 1,44 & 2,62 & 0,58 & $-3,93-6,82$ \\
\hline Respirasi & 1,52 & 0,00 & 0,28 & $-0,17-2,88$ \\
\hline Skor Kecemasan & 0,11 & 0,34 & 0,00 & $0,82-0,63$ \\
\hline \multicolumn{5}{|l|}{ Olah Raga } \\
\hline Tekanan Sistolik & 0,75 & 7,94 & 0,75 & $-4,29-5,79$ \\
\hline Tekanan Diastolik & 4,50 & 7,39 & 0,06 & $-0,19-9,12$ \\
\hline Nadi & 1,98 & 6,79 & 0,43 & $-5,89-2,73$ \\
\hline Respirasi & 1,33 & 2,22 & 0,63 & $-2,75-0,08$ \\
\hline Skor Kecemasan & 3,42 & 9,81 & 0,27 & $-2,82-9,65$ \\
\hline
\end{tabular}

Tabel 4. Perbedaan Rerata Tanda Tanda Vital dan Skor Kecemasan Bulan Pertama dan Bulan ke Tiga

\begin{tabular}{lcccc}
\hline Intervensi/variabel & Rerata & SD & $\boldsymbol{p}$-value & CI 95\% \\
\hline Latihan Yoga & & & & \\
Tekanan Sistolik & 3,33 & 12,28 & 0,30 & $-3,27-9,94$ \\
Tekanan Diastolik & 0,56 & 9,98 & 0,82 & $-4,40-5,52$ \\
Nadi & 1,83 & 5,02 & 0,14 & $-0,66-4,33$ \\
Respirasi & 0,61 & 1,38 & 0,08 & $-1,29-0,07$ \\
Skor Kecemasan & 13,50 & 10,33 & 0,00 & $0,03-0,81$ \\
Olahraga & & & & \\
Tekanan Sistolik & 0,75 & 7,94 & 0,75 & $-4,29-5,79$ \\
Tekanan Diastolik & 4,50 & 7,39 & 0,06 & $-0,19-9,12$ \\
Nadi & 1,98 & 6,79 & 0,43 & $-5,89-2,73$ \\
Respirasi & 1,33 & 2,22 & 0,63 & $-2,75-0,08$ \\
Skor Kecemasan & 3,42 & 9,81 & 0,27 & $-2,82-9,65$ \\
\hline
\end{tabular}

perlakuan dan setelah perlakuan yoga yakni pada skor kecemasan $(p<0,05)$. Berdasarkan hasil uji statistik tersebut dapat diasumsikan bahwa latihan yoga dapat menurunkan tingkat kecemasan saat menstruasi pada remaja puteri.

Latihan yoga menekankan konsentrasi yang memberi pengaruh positif yaitu ketenangan pikiran. Konsentrasi bisa menjadi sarana relaksasi pikiran yang sangat dibutuhkan oleh pikiran yang sedang stress. Latihan yoga secara teratur dapat menyeimbangkan sistem saraf otonom, sehingga tubuh menjadi lebih relaks dan pengeluaran hormon-hormon yang berperan dalam peningkatan tekanan darah, seperti hormon adrenalin dan epineprin lebih terkontrol.

Teknik senam yoga mengendalikan pernapasan dan pikiran. Latihan ini dapat menguatkan sistem pernapasan, menenangkan sistem saraf, membantu mengurangi dan menghilangkan kekacauan, dan dapat menguatkan sistem kekebalan tubuh. Pernapasan juga memainkan peranan penting dalam metabolisme tubuh, yaitu proses tubuh menguraikan nutrisi. 
Kecemasan merupakan hal wajar yang pernah dialami oleh setiap manusia. Kecemasan adalah suatu perasaan yang sifatnya umum, dimana seseorang merasa ketakutan atau kehilangan kepercayaan diri yang tidak jelas asal maupun wujudnya. Kecemasan adalah respon terhadap situasi tertentu yang mengancam, dan merupakan hal yang normal terjadi menyertai perkembangan, perubahan, pengalaman baru atau yang belum pernah dilakukan serta dalam menemukan identitas diri dan arti hidup.

Kecemasan dapat menimbulkan reaksi tubuh yang akan terjadi secara berulang seperti rasa kosong di perut, sesak nafas, jantung berdebar, keringat banyak, sakit kepala, mau buang air kecil atau buang air besar. Perasaan ini disertai perasaan ingin bergerak untuk lari menghindari hal yang dicemaskan (8). Hasil uji statistik menunjukan terdapat pengaruh yang bermakna antara sebelum perlakuan dan setelah perlakuan yoga yakni pada skor kecemasan $(p<0,05)$. Hal ini berarti bahwa latihan yoga dapat menurunkan tingkat kecemasan saat menstruasi remaja puteri. Latihan yoga yang diberikan pada kelompok intervensi dapat membuat tubuh menjadi lebih rileks dan meningkatkan konsentrasi sehingga kecemasan responden bisa berkurang. Hal yang sama diperkuat oleh teori yang menunjukkan bahwa latihan yoga dihubungkan dengan adanya peningkatan Gamma Amino Butyric Acis (GABA). GABA merupakan neurotransmitter yang memegang peranan penting dalam gejala-gejala gangguan jiwa. Fungsi utama GABA adalah menurunkan aurosal dan mengurangi agresi, kecemasan dan aktif dalam fungsi eksitasi. Yoga merupakan suatu metode yang unik untuk menyeimbangkan sistem saraf otonom dan memberikan pengaruh pada gangguan fisik dan gangguan gangguan yang berhubungan dengan stress. Teknik pernafasan yoga menyebabkan teradinya peningkatan kerja saraf parasimpatis, memberikan efek relaksasi, merangsang pelepasan oksitoksin dan disebut juga dengan latihan pernafasan yoga (7).

Di hipotalamus, oksitoksin dibuat di magneocelullar neurosecretory cells di supratopik dan nucleus paraventrikular. Oksitoksin dapat menginduksi anti stress serta memberikan efek dalam menurunkan kadar kortisol (9). Pemberian senam yoga dapat meningkatkan kadar oksitoksin dalam darah, sehingga efek ansiolitik yang dikeluarkan dapat menurunkan kecemasan. Yoga juga meningkatkan produksi endorfin yang merupakan hormon ansietas yang tentunya juga menurunkan kecemasan (10).
Yoga yang terjadi pada tubuh diawali dengan terciptanya suasana relaksasi alam sadar yang secara sistematis membimbing pada keadaan relaks yang mendalam. Terciptanya relaksasi akan menghilangkan suara-suara dalam pikiran sehingga tubuh akan mampu untuk melepas ketegangan otot. Ketika tubuh mulai rileks nafas menjadi santai dan dalam, sehingga sistem pernapasan dapat beristirahat (7). Melambatnya ritme pernafasan ini akan membuat detak jantung lebih lambat dan memberikan pengaruh positif terhadap keseluruhan sistem sirkulasi dan jantung untuk beristirahat dan mengalami proses peremajaan.

Kecemasan merupakan hal wajar yang pernah dialami oleh setiap manusia. Kecemasan sudah dianggap sebagai bagian dari kehidupan sehari-hari. Kecemasan adalah suatu perasaan yang sifatnya umum, dimana seseorang merasa ketakutan atau kehilangan kepercayaan diri yang tidak jelas asal maupun wujudnya (11). Kecemasan adalah respon emosional terhadap penilaian yang menggambarkan keadaan khawatir, gelisah, takut, tidak tentram disertai berbagai keluhan fisik. Keadaan tersebut dapat terjadi dalam berbagai situasi kehidupan maupun gangguan sakit. Selain itu kecemasan dapat menimbulkan reaksi tubuh yang akan terjadi secara berulang seperti rasa kosong di perut, sesak nafas, jantung berdebar, keringat banyak, sakit kepala, mau buang air kecil atau buang air besar. Perasaan ini disertai perasaan ingin bergerak untuk lari menghindari hal yang dicemaskan (8). Kecemasan adalah gejala yang tidak spesifik dan aktifitas saraf otonom dalam berespon terhadap ketidakjelasan, ancaman tidak spesifik yang sering ditemukan dan sering kali merupakan emosi yang normal.

\section{SIMPULAN DAN SARAN}

Terjadi penurunan tanda tanda vital pada siklusmentruasi remaja puteri pada kelompok yoga dan olah raga. Secara statistik tidak terdapat pengaruh yang signifikan latihan yoga terhadap tekanan sistolik, diastolik, frekuensi nadi dan pernafasan, namun hasil penelitian menunjukkan yoga dapat menurunkan tekanan sistolik, tekanan diastolik menurun lebih banyak terjadi pada kelompok olahraga sebesar 4,50 sedangkan yoga sebesar 0,55 . Pada kelompok yoga terjadi penurunan frekuensi denyut nadi yakni sebesar 1,83. Yoga secara signifikan dapat menurunkan tingkat kecemasan remaja puteri pada saat menstruasi. 
Kegiatan olahraga di institusi pendidikan dapat dilakukan dengan berbagai variasi tidak hanya bentuk olahraga yang konvensional saja. Untuk meningkatkan kesehatan reproduksi senam/olahraga khusus untuk remaja puteri yoga sangat dianjurkan. Perlu adanya alokasi waktu khusus untuk fasilitasi agar mahasiswa dapat melakukan kegiatan olah raga, mengingat waktu pembelajaran mahasiswa $D$ III Kebidanan cukup padat.

\section{RUJUKAN}

1. Novia I, Puspitasari N. Faktor Risiko yang Mempengaruhi Kejadian Dismenore Primer. Indones J Public Heal. 2008;4(3):96-103.

2. Matsumoto T, Ushiroyama T, Kimura T, Hayashi $\mathrm{T}$, Moritani T. Altered autonomic nervous system activity as a potential etiological factor of premenstrual syndrome and premenstrual dysphoric disorder. Biopsychosoc Med [Internet]. 2007 Dec 20;1:24. Available from: http://www. ncbi.nlm.nih.gov/pubmed/18096034.

3. Zaafrane F, Faleh R, Melki W, Sakouhi M, Gaha L. [An overview of premenstrual syndrome]. J Gynecol Obstet Biol Reprod (Paris) [Internet]. 2007 Nov;36(7):642-52. Available from: http:// www.ncbi.nlm.nih.gov/pubmed/17321695.

4. Ross A, Thomas S. The health benefits of yoga and exercise: a review of comparison studies. J Altern Complement Med [Internet]. 2010
Jan;16(1):3-12. Available from: http://www.ncbi. nlm.nih.gov/pubmed/20105062.

5. Beck AT, Steer R. Psychological parameters: BAI (Beck Anxiety Inventory).

6. Bare B, Smeltxer S. Buku Ajar Keperawatan Medical Bedah. Jakarta: EGC; 2001.

7. Sengupta P. Health Impacts of Yoga and Pranayama: A State-of-the-Art Review. Int J Prev Med [Internet]. Medknow Publications; 2012 Jul [cited 2017 Mar 2];3(7):444-58. Available from: http://www.ncbi.nlm.nih.gov/pubmed/22891145.

8. Parshad O, Richards A, Asnani M. Impact of yoga on haemodynamic function in healthy medical students. West Indian Med J [Internet]. 2011 Mar;60(2):148-52. Available from: http://www. ncbi.nlm.nih.gov/pubmed/21942118.

9. Dvivedi J, Dvivedi S, Mahajan KK, Mittal $S$, Singhal A. Effect of "61-points relaxation technique" on stress parameters in premenstrual syndrome. Indian J Physiol Pharmacol [Internet]. 2008;52(1):69-76. Available from: http://www. ncbi.nlm.nih.gov/pubmed/18831354.

10. Neuman ID, Landgraf R. Advances in Vasopressin and Oxytocin to Behaviour to Disease. British: Elsevier Publication; 2008.

11. Vempati RP, Telles S. Yoga-based guided relaxation reduces sympathetic activity judged from baseline levels. Psychol Rep [Internet]. 2002 Apr;90(2):487-94. Available from: http://www. ncbi.nlm.nih.gov/pubmed/12061588. 